\title{
Transcriptome Analysis of the Fruit of Two Strawberry Cultivars "Sunnyberry" and "Kingsberry" That Show Different Susceptibility to Botrytis cinerea after Harvest
}

\author{
Kyuweon Lee ${ }^{1, \dagger}$, Jeong Gu Lee ${ }^{1, \dagger}$, Kyeonglim Min ${ }^{1}$, Jeong Hee Choi ${ }^{2}$, Sooyeon Lim ${ }^{3}$ and Eun Jin Lee ${ }^{1,4, *}$ \\ 1 Department of Agriculture, Forestry and Bioresources, College of Agriculture and Life Sciences, \\ Seoul National University, Seoul 08826, Korea; lkwjudy@snu.ac.kr (K.L.); tto12321@snu.ac.kr (J.G.L.); \\ mk10228@snu.ac.kr (K.M.) \\ 2 Korea Food Research Institute, Wanju-gun, Jeollabuk-do 55365, Korea; choijh@kfri.re.kr \\ 3 National Institute of Horticultural and Herbal Science, Rural Development Administration, \\ Wanju-gun 55365, Korea; sylim84@korea.kr \\ 4 Research Institute of Agriculture and Life Sciences, Seoul National University, Seoul 08826, Korea \\ * Correspondence: ejinlee3@snu.ac.kr \\ + These authors contributed equally to this work.
}

Citation: Lee, K.; Lee, J.G.; Min, K.;

Choi, J.H.; Lim, S.; Lee, E.J.

Transcriptome Analysis of the Fruit of Two Strawberry Cultivars

"Sunnyberry" and "Kingsberry" That Show Different Susceptibility to Botrytis cinerea after Harvest. Int. J. Mol. Sci. 2021, 22, 1518. https:// doi.org/10.3390/ijms22041518

Academic Editor: Lam-Son Phan Tran Received: 22 January 2021

Accepted: 1 February 2021

Published: 3 February 202

Publisher's Note: MDPI stays neutral with regard to jurisdictional claims in published maps and institutional affiliations.

Copyright: () 2021 by the authors. Licensee MDPI, Basel, Switzerland. This article is an open access article distributed under the terms and conditions of the Creative Commons Attribution (CC BY) license (https:// creativecommons.org/licenses/by/ $4.0 /)$
Abstract: Gray mold (Botrytis cinerea) is a fungal plant pathogen causing postharvest decay in strawberry fruit. Here, we conducted a comparative transcriptome analysis to identify differences in gene expression between the immature-green (IG) and mature-red (MR) stages of the "Sunnyberry" (gray mold-resistant) and "Kingsberry" (gray mold susceptible) strawberry cultivars. Most of the genes involved in lignin and alkane-type wax biosynthesis were relatively upregulated in "Sunnyberry". However, pathogenesis-related proteins encoding $\mathrm{R}$ - and antioxidant-related genes were comparatively upregulated in "Kingsberry". Analysis of gene expression and physiological traits in the presence and absence of $B$. cinerea inoculation revealed that the defense response patterns significantly differed between IG and MR rather than the cultivars. "Kingsberry" showed higher antioxidant induction at IG and upregulated hemicellulose-strengthening and R genes at MR. Hence, "Sunnyberry" and "Kingsberry" differed mainly in terms of the expression levels of the genes forming cuticle, wax, and lignin and controlling the defense responses. These discrepancies might explain the relative difference between these strawberry cultivars in terms of their postharvest responses to B. cinerea.

Keywords: cell wall; cuticle; gene expression; harvest; storage; strawberry fruit; transcriptome; wax

\section{Introduction}

Strawberry (Fragaria $\times$ ananassa Duch.) is an economically important horticultural crop. The export value of strawberries in Korea increases annually. Strawberry production and exportation have risen more than threefold over the past two decades [1]. Overall strawberry production reached nine million tons in 2016 and over ten percent of the fruit is exported. However, postharvest strawberry fruit is perishable and susceptible to mechanical damage, fungal decay, and rapid metabolism. Severe deterioration of postharvest fruit quality and economic loss may be the consequences of small scratches and bruises during packaging and shipping [2,3]. Strawberry fruit readily senesces after harvest and has a short shelf life because it is highly sensitive to biotic and abiotic stress [4].

Botrytis cinerea is a devastating postharvest fungal pathogen on strawberry. It infects mainly the floral organs and is quiescent during fruit ripening. This necrotroph obtains its nutrients from dead fruit tissues [5]. When $B$. cinerea spores attach to the host surface, they extend germ tubes to reach suitable infection sites. They then penetrate the host cells via appressoria and infection hyphae [6]. B. cinerea secretes cutinase and polygalacturonase (PG) as well as phytotoxic compounds to facilitate host penetration and infection [7]. 
Plants have evolved defense mechanisms against postharvest fungal pathogens [8]. Cuticles and cell walls are primary barriers that limit pathogen attack and release signaling molecules that activate defense responses [9-11]. Pattern recognition receptors and immune signaling transduction systems transmit signals that induce defense-related genes and transcription factors [12,13]. Xiong et al. [14] reported that $>1500$ defense-related genes are induced after $B$. cinerea inoculation in mature-red (MR) strawberry fruit. Complex crosstalk among jasmonic acid, salicylic acid, ethylene, and abscisic acid participates in defense responses by regulating defense-, ripening-, and senescence-related genes [12,15]. Reactive oxygen species (ROS) and enzymatic or non-enzymatic antioxidant systems may play important roles in defense responses. ROS are secondary messengers that induce phytohormone responses and defense-related genes. Nevertheless, excessive ROS damage the fruit [16].

Next-generation sequencing identifies factors that contribute to fungal pathogen resistance in horticultural crops. Several researchers have attempted to identify the differences between resistant and susceptible cultivars in terms of defense response [17-19]. Certain studies have compared the transcriptomes of resistant and sensitive cultivars in the absence of pathogen attack $[20,21]$. Other studies have compared defense responses between unripe and ripe fruits because $B$. cinerea is quiescent in green fruit [22-24].

Resistance to postharvest fungal decay in strawberries depends largely on the genetic background of the cultivar. Dong et al. [25] reported that the fungal decay rates of postharvest strawberry fruit significantly differed among genotypes. They were not correlated with total phenolic or soluble sugar content but were correlated with firmness. No strawberry cultivar is fully resistant to B. cinerea. Studies on various B. cinerea-resistant strawberry cultivars have been conducted. An earlier work assessed postharvest storability in five different strawberry cultivars developed in Korea [3]. The "Sunnyberry" and "Kingsberry" varieties were the most resistant and susceptible to postharvest fungal decay, respectively.

To the best of our knowledge, no prior research has compared the transcriptomes of strawberry cultivars with different responses to $B$. cinerea. Here, we compared the transcriptomes of the aforementioned "Sunnyberry" and "Kingsberry" strawberry cultivars. We characterized their differentially expressed genes (DEGs) involved in pre-formed and induced defense responses. We determined the relative expression levels of several genes by quantitative polymerase chain reaction (qPCR) analysis. We evaluated the physiological traits of these fruit varieties in the presence and absence of $B$. cinerea inoculation. This study will help clarify the various defense responses in two different strawberry cultivars and identify the genetic factors that probably contribute to $B$. cinerea resistance in this crop. Our findings will also provide a theoretical basis for selecting and breeding strawberry cultivars with enhanced postharvest fruit storability.

\section{Results}

\section{1. "Sunnyberry" Cultivar Is More Resistant to B. cinerea Than "Kingsberry" Cultivar}

We used two methods to compare the resistance of "Sunnyberry" and "Kingsberry" strawberry fruit to $B$. cinerea at the MR stage (Figure 1). First, we stored the fruit at the MR stage at $10^{\circ} \mathrm{C}$ for $10 \mathrm{~d}$ without $B$. cinerea inoculation. Disease symptoms initially appeared in "Kingsberry" after $3 \mathrm{~d}$ and in "Sunnyberry" after $5 \mathrm{~d}$. Disease incidence rapidly increased in "Kingsberry" after $5 \mathrm{~d}$ storage and reached $68 \%$ after $10 \mathrm{~d}$ but only $19 \%$ in "Sunnyberry" by the same time (Figure 1B). Second, we inoculated strawberry fruits with $B$. cinerea conidia and stored them at $25^{\circ} \mathrm{C}$ for $10 \mathrm{~d}$. By the end of this period, most of the "Sunnyberry" fruits presented with only small lesions and very few pathogen mycelia. In contrast, most of the "Kingsberry" fruits were very soft and bore numerous B. cinerea hyphae (Figure 1A). The disease index markedly increased 5-day post-inoculation (dpi) (Figure 1C). 


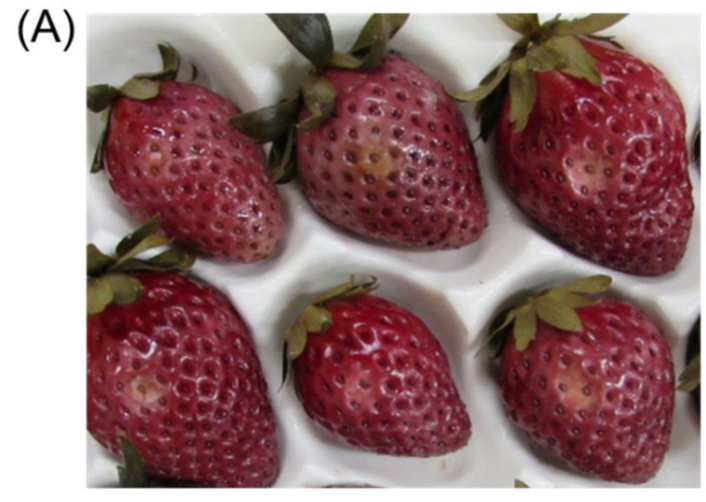

'Sunnyberry'

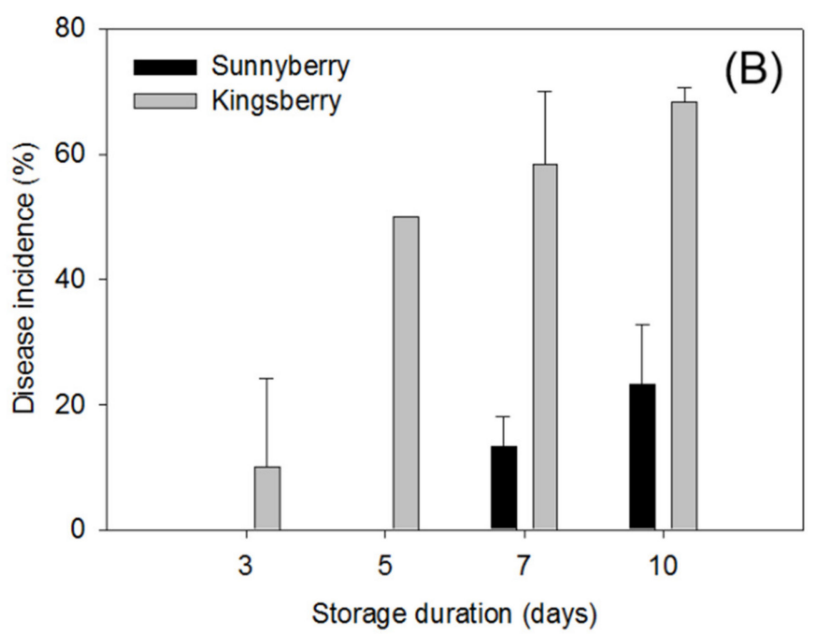

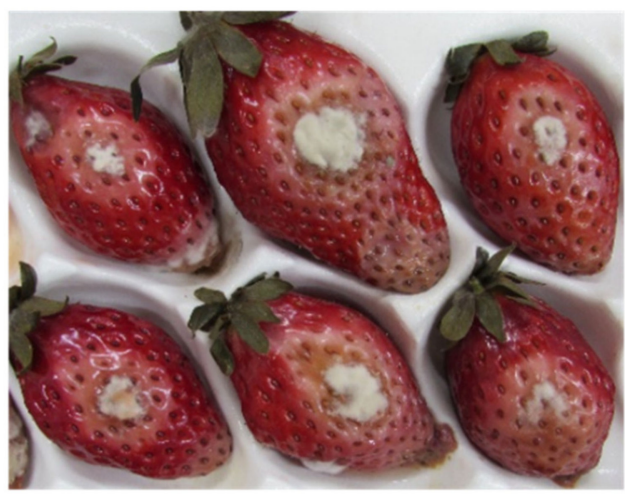

'Kingsberry'

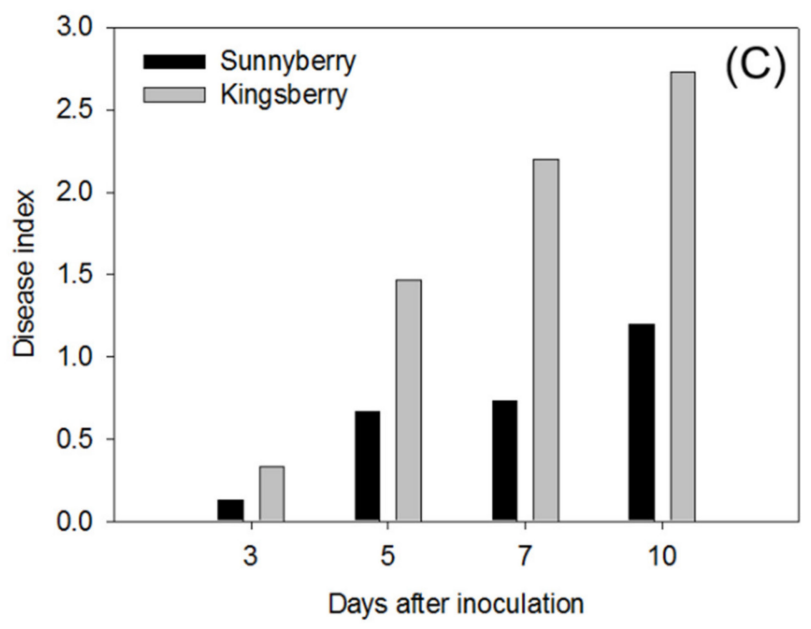

Figure 1. "Sunnyberry" and "Kingsberry" strawberry fruit inoculated with Botrytis cinerea. (A) Fruit at $10 \mathrm{~d}$ post-inoculation. (B) Disease incidence during $10 \mathrm{~d}$ storage at $10{ }^{\circ} \mathrm{C}$ in the absence of $B$. cinerea inoculation. (C) Disease index during $10 \mathrm{~d}$ storage at $25^{\circ} \mathrm{C}$ post-inoculation. Data are means $\pm \mathrm{SD}$.

\subsection{Comparison of "Sunnyberry" and "Kingsberry" Transcriptomes}

The transcriptomes of the two strawberry fruit cultivars at the immature-green (IG) and MR stages were compared. Fifty-five million reads per sample were obtained through RNA sequencing (RNA-Seq) (Table S1). In "Sunnyberry", 692 DEGs were relatively upregulated only at IG and 2487 DEGs were relatively upregulated only at MR (Figure 2A). For "Kingsberry", 950 DEGs were relatively upregulated only at IG and 2963 DEGs were relatively upregulated only at MR (Figure 2B). The DEGs were subjected to functional analysis by gene ontology (GO) term annotation (Figure 2C,D). The top five $\mathrm{GO}$ categories were "cellular process", "cell", "cell part", "catalytic activity", and "metabolic process" at both IG and MR. 

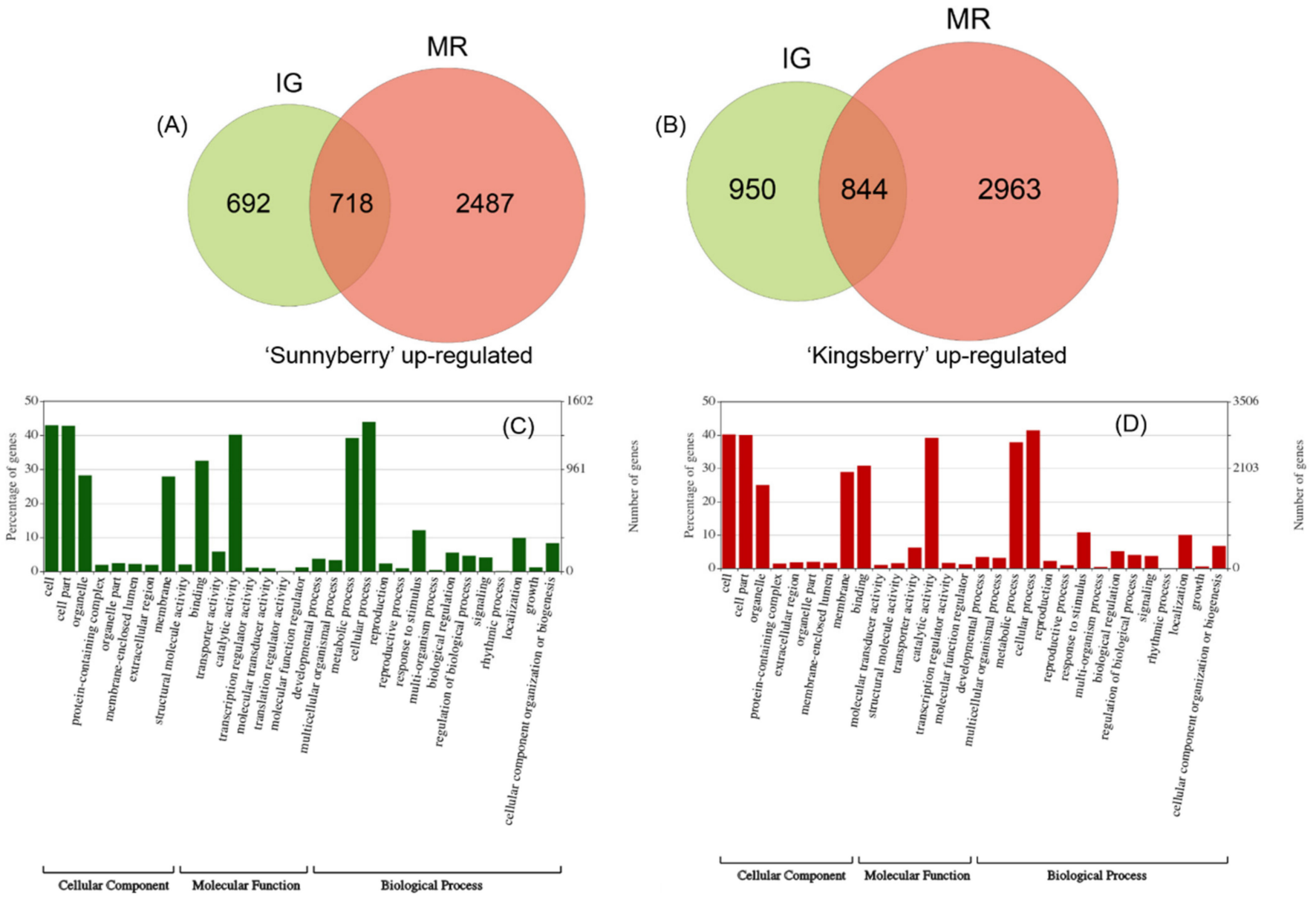

Figure 2. Transcriptomes of "Kingsberry" and "Sunnyberry" strawberry fruit. (A) Upregulated DEGs in "Sunnyberry" at IG and MR. (B) Upregulated DEGs in "Kingsberry" at IG and MR. GO annotation of DEGs at IG (C) and MR (D). DEGs were filtered using the false discovery rate (FDR) criteria $p<0.01$ and $\mid$ Fold change $\mid>2$. DEGs, differentially expressed genes; GO, gene ontology; IG, immature-green; MR, mature-red.

\subsection{Lignin Biosynthesis-Related Genes Were Relatively Upregulated in B. cinerea-Resistant "Sunnyberry" Cultivar}

Genes related to cell wall metabolism were differentially expressed between the "Sunnyberry" and "Kingsberry" cultivars (Table S2). At IG, endoglucanase genes were upregulated in "Sunnyberry" compared with those in "Kingsberry". At MR, COBRA-like protein genes were upregulated in "Kingsberry" relative to "Sunnyberry". At both IG and MR, exo-PG and pectate lyase (PL) genes were upregulated in "Sunnyberry" compared with those in "Kingsberry". At MR, polygalacturonase $1 \beta$-like protein 3 (PGL3) [26], pectin acetylesterase (PAE), and pectin methylesterase (PME) genes were upregulated in "Kingsberry" relative to "Sunnyberry".

Here, we identified DEGs involved in lignin biosynthesis (Figure 3; Table S3). At both IG and MR, caffeic acid O-methyltransferase, cinnamoyl-CoA reductase 1 (CCR1), and cinnamyl alcohol dehydrogenase (CAD) genes were upregulated in "Sunnyberry" compared with those in "Kingsberry". In contrast, at IG and MR, caffeoyl-CoA O-methyltransferase genes were upregulated in "Kingsberry" relative to "Sunnyberry". Certain CAD genes were annotated as putative mannitol dehydrogenases. Nevertheless, these genes may be functionally redundant and could be considered CAD [27]. Class III peroxidases (PODs) and laccases (LACs) polymerize monolignol units into lignin. At MR, most DEGs annotated as $P O D$ and $L A C$ were upregulated in "Sunnyberry" compared with those in "Kingsberry". 
p-Coumaroyl shikimic acid<smiles>C[AlH2]</smiles>
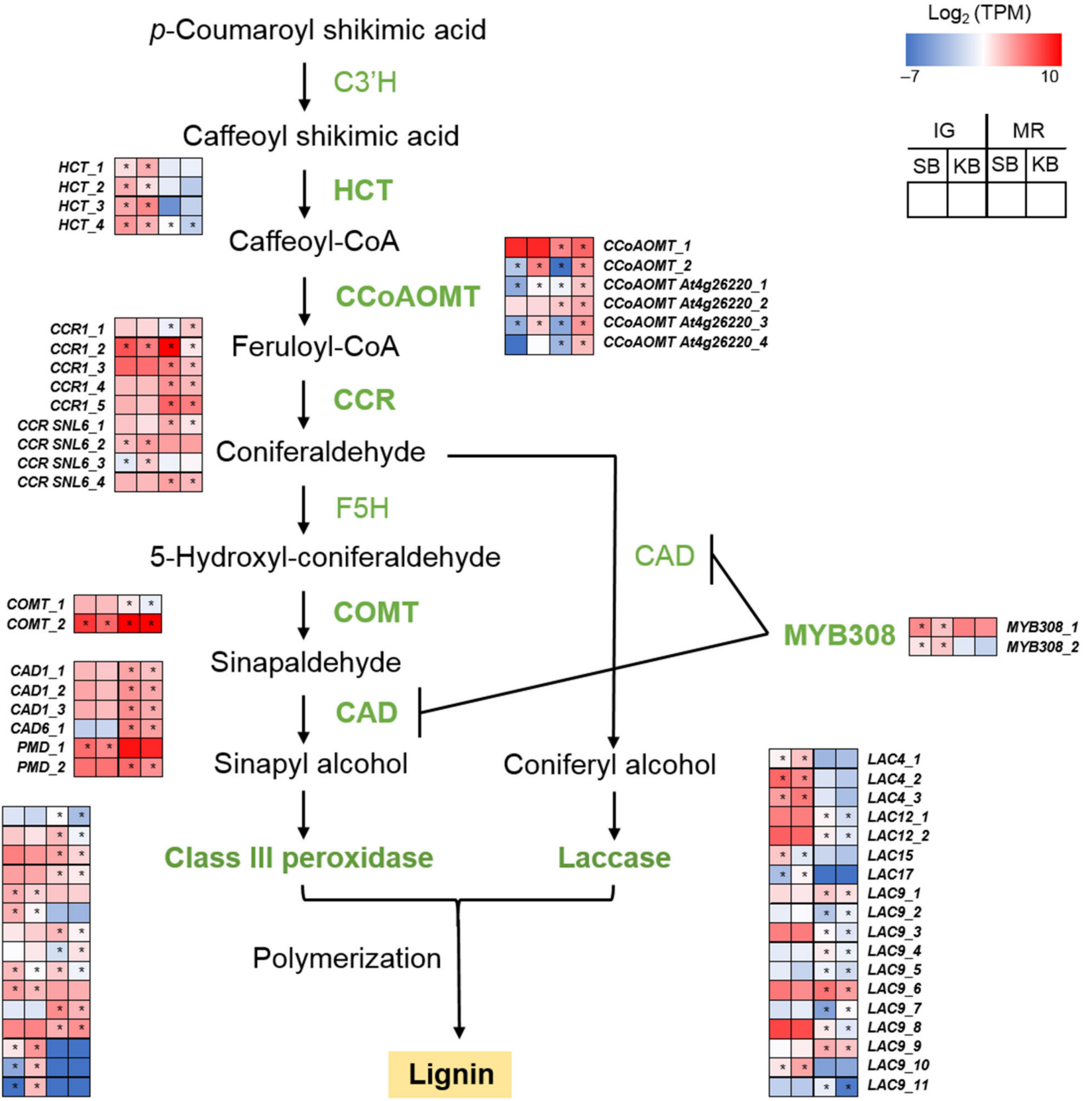

Figure 3. Lignin biosynthesis gene expression patterns at IG and MR of "Sunnyberry" and "Kingsberry" strawberry fruit. C3'H, p-coumaroyl shikimate 3'-hydroxylase; CAD, cinnamyl alcohol dehydrogenase; CCoAOMT, caffeoyl-CoA Omethyltransferase; CCR, cinnamoyl-CoA reductase; COMT, caffeic acid O-methyltransferase; F5H, ferulic acid 5-hydroxylase; HCT, shikimate O-hydroxycinnamoyltransferase; IG, immature-green; KB, "Kingsberry" cultivar; LAC, laccase; MR, maturered; PMD, probable mannitol dehydrogenase; POD, peroxidase; SB, “Sunnyberry" cultivar; TPM, transcripts per million. Asterisks indicate statistically significant differences between cultivars (FDR $p<0.01$; | Fold change $\mid>2$ ).

\subsection{Alkane-Type Cuticle Biosynthesis-Related Genes Were Relatively Upregulated in B. cinerea-Resistant "Sunnyberry"}

Cuticular wax is biosynthesized by fatty acid elongation, decarbonylation, and acyl reduction [28]. Here, we identified DEGs encoding long-chain acyl-CoA synthetase (LACS), 3-ketoacyl-CoA synthase, 3-ketoacyl-CoA reductase, and 3-hydroxyacyl-CoA dehydratase (HCD) (Figure 4; Table S4). At IG and MR, HCD was comparatively upregulated in "Kingsberry". However, there was no trend in the expression of any other DEGs involved in fatty acid elongation. Protein ECERIFERUM 1-like (CER1) genes mediate decarbonylation of 
very long-chain fatty acids (VLCFAs) and were comparatively upregulated in "Sunnyberry" at IG and MR. Wax ester synthase/diacylglycerol O-acyltransferase (WSD) genes mediate acyl reduction of VLCFAs and were relatively upregulated in "Kingsberry" at both stages.

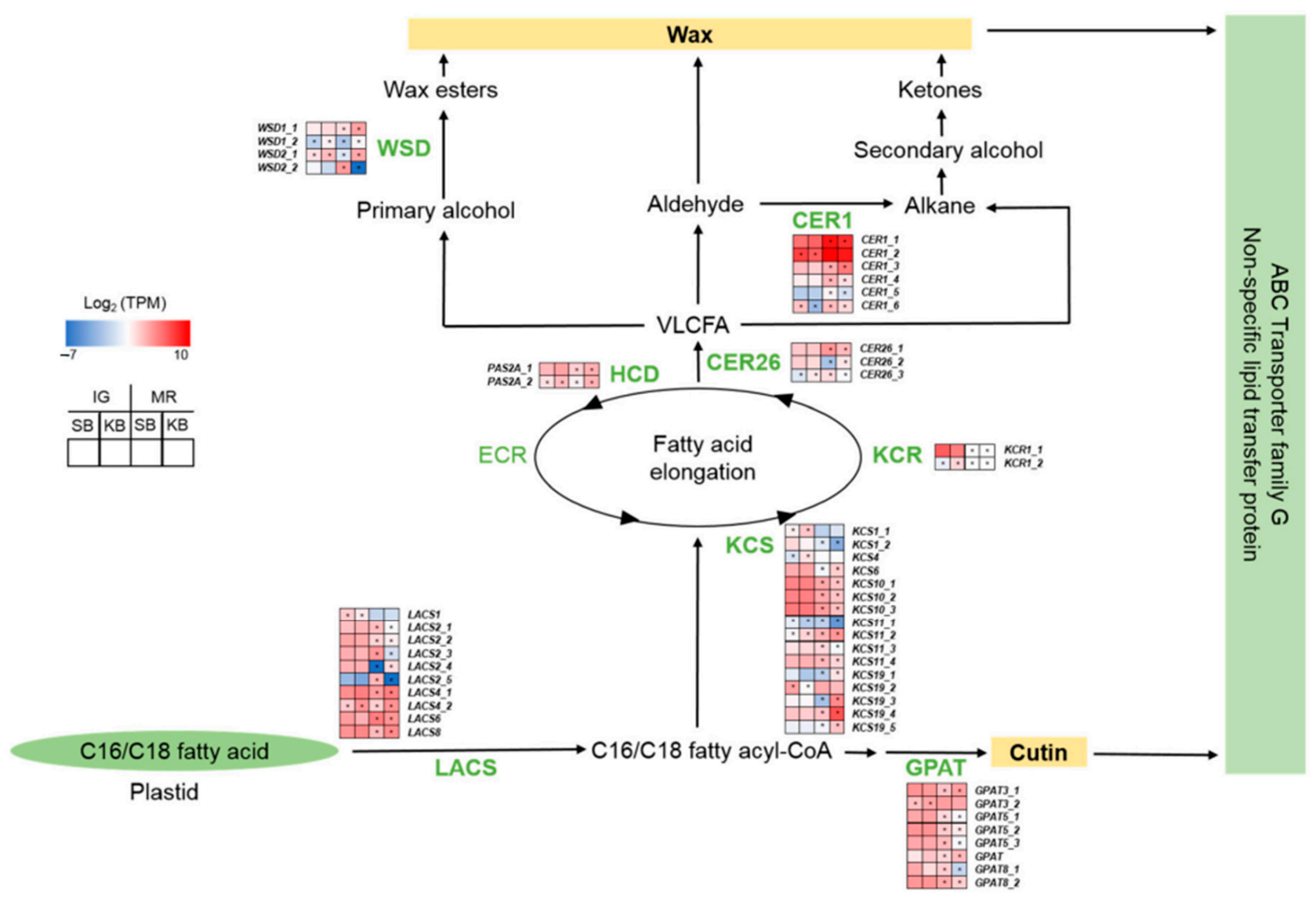

Figure 4. Expression patterns of cuticle biosynthesis genes at IG and MR in "Sunnyberry" and "Kingsberry" strawberry fruit. CER, protein ECERIFERUM; ECR, enoyl-CoA reductase; GPAT, glycerol-3-phosphate acyltransferase; HCD, 3-hydroxyacylCoA dehydratase; IG, immature-green; KB, "Kingsberry" cultivar; KCR, 3-ketoacyl-CoA reductase; KCS, 3-ketoacyl-CoA synthase; LACS, long-chain acyl-CoA synthetase; MR, mature-red; PAS2A, very-long-chain (3R)-3-hydroxyacyl-CoA dehydratase PASTICCINO 2A; SB, "Sunnyberry" cultivar; TPM, transcripts per million; WSD, wax ester synthase/diacylglycerol $O$-acyltransferase. Asterisks indicate statistically significant differences between cultivars (FDR $p<0.01 ; \mid$ Fold change | $>2$ ).

\section{5. $R$ Genes Were Relatively Upregulated in B. cinerea-Susceptible "Kingsberry"}

Certain pathogenesis-related (PR) genes were identified as DEGs (Table S5). At MR, endochitinase (CHI) and glucan endo-1,3- $\beta$-glucosidase ( $\beta$ GLU) genes were upregulated in "Kingsberry" compared with those in "Sunnyberry". CHI and $\beta$ GLU degrade chitins and glucans in fungal cell walls [29]. Thaumatin-like proteins (TLPs) are PR-5 class proteins. They were upregulated in "Sunnyberry" relative to "Kingsberry" at MR. In wild peanut (Arachis diogoi Hoehne), TLP was upregulated after Phaeoisariopsis personata (late leaf spot fungus) inoculation. In vitro, recombinant TLPs presented with activity against several fungal pathogens, including B. cinerea [30].

At both IG and MR, most DEGs encoding RPM 1-like protein and RPP13-like protein 1 were relatively upregulated in "Kingsberry". Several bioinformatically predicted resistance gene analogs [31] were also identified as DEGs here.

\subsection{Antioxidant System-Related Genes Were Relatively Upregulated in "Kingsberry"}

At IG and MR, the antioxidant peroxiredoxin (PRX) and superoxide dismutase were comparatively upregulated in "Kingsberry" (Table S6). The thiol peroxidase PRX partici- 
pates in antioxidant defense. PrxIIE and PrxQ remove ROS, such as NO, that accumulate in response to biotic stress [32]. The 2-hydroxyisoflavanone dehydratase and dihydroflavonol4-reductase genes are involved in flavonoid and isoflavonoid biosynthesis. At MR, they were upregulated in "Kingsberry" relative to "Sunnyberry". At IG and MR, two leucoanthocyanidin reductase (LAR) genes were upregulated in "Kingsberry" compared with those in "Sunnyberry".

2.7. Changes in Gene Expression Following B. cinerea Inoculation Revealed Differences between "Sunnyberry" and "Kingsberry" in Terms of Defense Response

Eight DEGs were selected at the IG and MR stages of "Sunnyberry" and "Kingsberry" in the presence or absence of $B$. cinerea inoculation. Their relative expression levels were measured by qPCR (Figure 5). In total, $5 \mathrm{dpi}$ fruits were used for IG and $10 \mathrm{dpi}$ fruits were used for MR. MR fruits sampled later as "Sunnyberry" and "Kingsberry" differed in terms of disease index at $5 \mathrm{dpi}$ (Figure 1C).

In both cultivars, $C A D$ was upregulated after $B$. cinerea inoculation only at IG while cellulose synthase-like protein D3 (CSLD3) was upregulated after B. cinerea inoculation only at MR. At MR, CCR1 was relatively upregulated in "Sunnyberry". However, B. cinerea inoculation dramatically lowered CCR1 mRNA in both cultivars at MR.

In the absence of B. cinerea inoculation, CER1 was upregulated in "Sunnyberry" compared with that in "Kingsberry" at IG and MR. The opposite was true after B. cinerea inoculation. LACS4 was upregulated after B. cinerea inoculation only at MR. In the presence and absence of $B$. cinerea inoculation, LACS4 had higher expression levels in "Kingsberry" than in "Sunnyberry" at MR.

The relative mRNA level of $\beta G L U$ presented with very wide SD. Hence, it did not significantly differ between cultivars. In the presence and absence of $B$. cinerea inoculation, $T L P 1 b$ was relatively upregulated in "Sunnyberry" but was significantly suppressed at MR by inoculation. RPM1 was comparatively upregulated in "Kingsberry" at IG and MR but its relative mRNA level was substantially higher at MR. RPM1 was upregulated in MR fruits after B. cinerea inoculation. "Kingsberry" showed higher relative RPM1 mRNA levels after $B$. cinerea inoculation.

\subsection{Physiological Traits Were Altered by B. cinerea Inoculation but Did Not Significantly Differ between Cultivars at $M R$}

Hydrogen peroxide $\left(\mathrm{H}_{2} \mathrm{O}_{2}\right)$ content, total phenolic content, and total antioxidant activity were determined in the presence and absence of $B$. cinerea inoculation (Figure 6). At IG, the $\mathrm{H}_{2} \mathrm{O}_{2}$ content was significantly higher in "Kingsberry" than in "Sunnyberry" at 5 dpi (Figure 6A). Total phenolic compound content and total antioxidant activity were relatively higher in "Kingsberry" in the presence and absence of $B$. cinerea inoculation (Figure 6B,C). Total antioxidant activity significantly increased in "Kingsberry" after $B$. cinerea inoculation.

At MR, however, there were no significant differences in $\mathrm{H}_{2} \mathrm{O}_{2}$ content, total phenolic content, or total antioxidant activity between cultivars or inoculation treatments. In contrast, the lignin content significantly increased after B. cinerea inoculation in "Sunnyberry" at MR (Figure 6D). However, there were no significant differences between cultivars. 

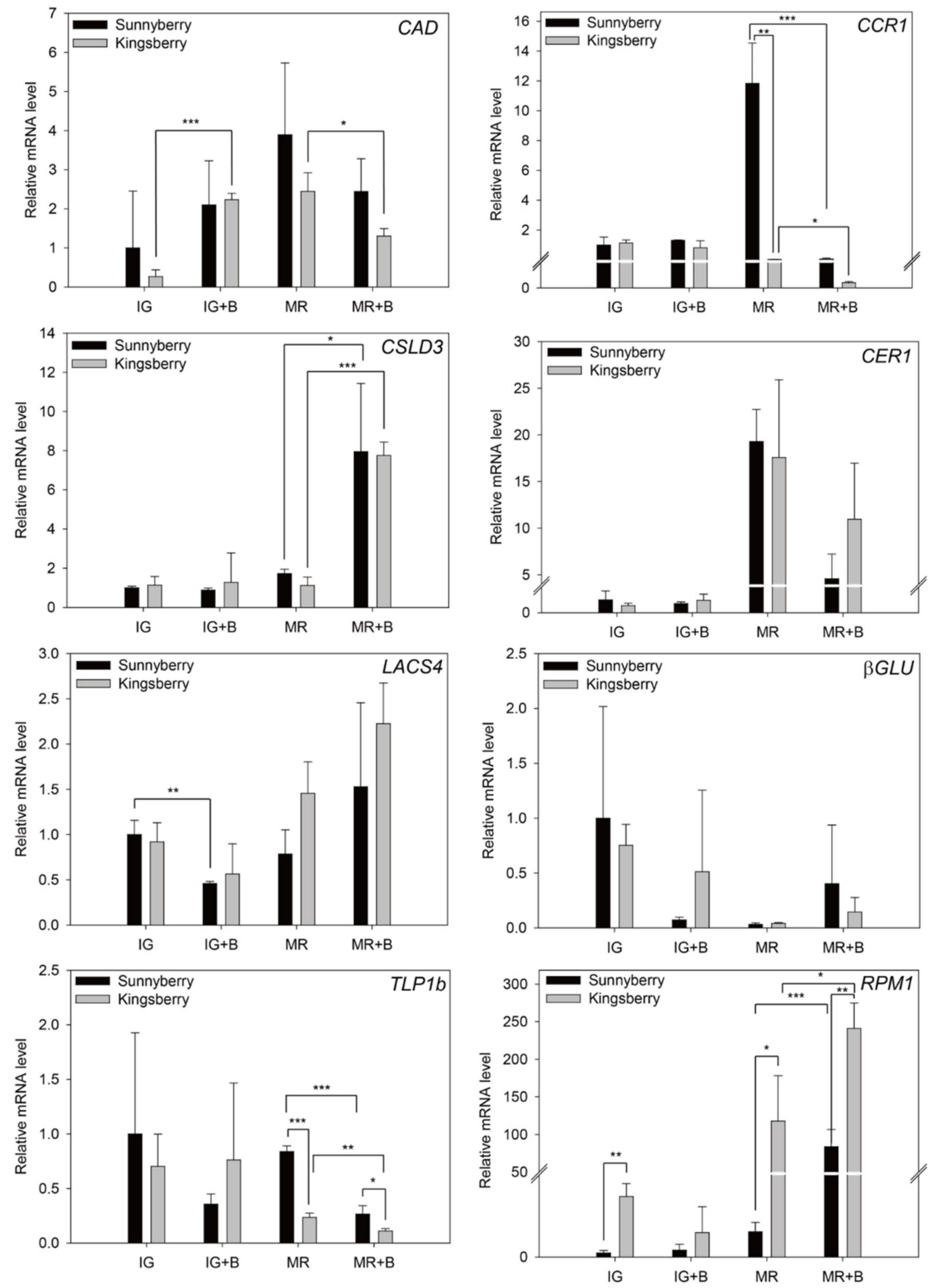

Figure 5. qPCR analysis of eight DEGs in "Sunnyberry" and "Kingsberry" strawberry fruit in the presence or absence of Botrytis cinerea inoculation. Relative mRNA levels of genes related to cell wall metabolism (CAD, CCR1, and CSLD3), cuticle biosynthesis (CER1 and LACS4), and defense responses ( $\beta G L U, T L P 1 b$, and RPM1). $\beta G L U$, glucan endo-1, 3- $\beta-$ glucosidase; $C A D$, cinnamyl alcohol dehydrogenase; $C C R 1$, cinnamoyl-CoA reductase 1; CER1, protein ECERIFERUM 1; CSLD3, cellulose synthase-like protein D3; IG, immature-green fruit without inoculation; IG + B, immature-green fruit at 5 days after inoculation; LACS4, long-chain acyl-CoA synthetase 4; MR, mature-red fruit without inoculation; MR + B, mature-red fruit at 10 days after inoculation; RPM1, disease resistance protein RPM 1-like; TLP1b, thaumatin-like proteins. Data are means $\pm \mathrm{SD}$ for three biological replicates. Asterisks indicate statistically significant differences between cultivars. ${ }^{*}, p<0.05 ;{ }^{* *}, p<0.01 ; * *, p<0.001$. 

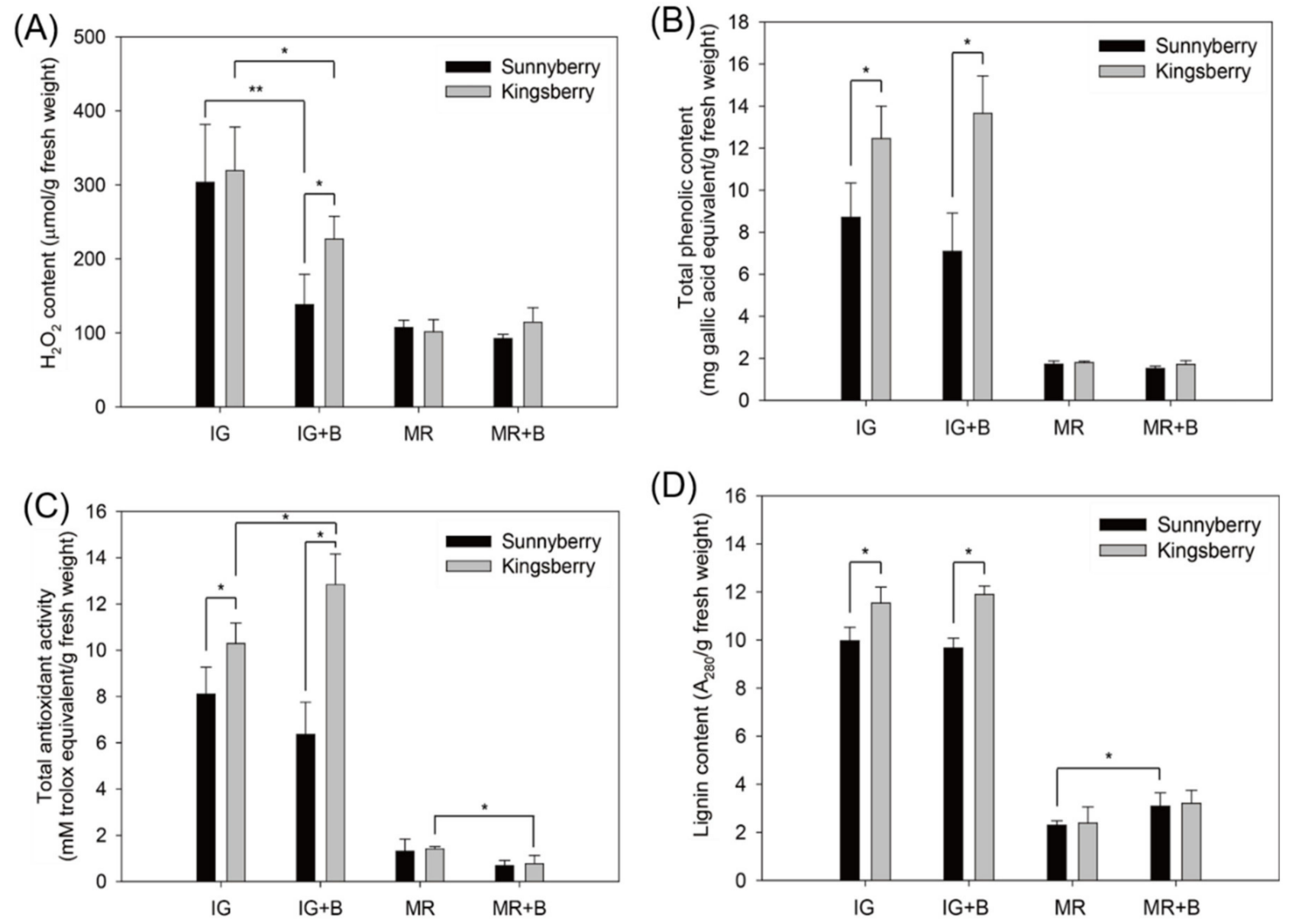

Figure 6. Changes in the physiological properties of "Sunnyberry" and "Kingsberry" strawberry. (A) $\mathrm{H}_{2} \mathrm{O}_{2}$ content, (B) total phenolic content, (C) total antioxidant activity, and (D) lignin content. IG, immature-green fruit without inoculation; IG + B, immature-green fruit at $5 \mathrm{~d}$ after inoculation; $\mathrm{MR}$, mature-red fruit without inoculation; $\mathrm{MR}+\mathrm{B}$, mature-red fruit at $10 \mathrm{~d}$ after inoculation. Data are means $\pm \mathrm{SD}$ for four biological replicates. Asterisks indicate statistically significant differences between cultivars. ${ }^{*}, p<0.05 ;{ }^{* *}, p<0.01$.

\section{Discussion}

In the present study, we evaluated the transcriptomic differences between a strawberry cultivar showing resistance to B. cinerea ("Sunnyberry") and one that is susceptible to this fungal pathogen ("Kingsberry"). We also measured the relative expression levels of eight selected DEGs and compared the physiological traits of these strawberry varieties in the presence and absence of $B$. cinerea inoculation.

Cell wall-degrading enzymes soften and crack the fruit and facilitate $B$. cinerea penetration and invasion [33]. They affect strawberry fruit firmness and susceptibility to $B$. cinerea. $P G$ and $P L$ were relatively upregulated in "Sunnyberry" while PGL3, PAE, and PME were comparatively upregulated in "Kingsberry" (Table S2). Different pectin-degrading enzymes may have been activated in each cultivar and had different relative influences on fruit firmness and B. cinerea susceptibility.

Cell wall biosynthesis enzymes reinforce plant cells against pathogen attack by depositing lignin, strengthening cross-linkages, and changing wall component ratios [9]. Lignin is a major component of the secondary cell wall. In strawberry fruit, it is located mainly in the achenes and the vascular bundles [34]. Here, $C A D, C C R$, and other lignin biosynthesis-related genes were upregulated in "Sunnyberry" compared with those in "Kingsberry" (Figure 3; Table S3). 
Lignin biosynthesis-related genes may contribute to fungal pathogen resistance. $P O D$ and $C A D$ were expressed at higher levels in anthracnose-resistant than in anthracnosesusceptible tea plants [21]. In strawberry fruit, terpinen-4-ol treatment reduced the incidence of decay, upregulated phenylpropanoid pathway-related genes, and increased the lignin content [35]. Lignin biosynthesis-related genes also affect strawberry fruit firmness. $C A D$ and $C C R$ were the most differentially expressed genes in three strawberry cultivars and strongly influenced fruit firmness [36]. In this study, $C A D$ and $C C R$ were relatively upregulated in "Sunnyberry", and this cultivar presented with firmer and more pathogen-resistant fruit. Hence, these genes merit further investigation.

B. cinerea inoculation caused CAD upregulation at IG and CSLD3 upregulation at MR (Figure 5). The main defense response of strawberry fruit against $B$. cinerea at MR might be the reinforcement of the xyloglucan chains. Caño-Delgado et al. [37] suggested that cellulose and lignin compensate for each other to restore and maintain structural cell wall integrity. Strawberry fruit may differentially regulate cell wall composition against fungal attack depending on the developmental stage. Here, however, there were no significant differences between "Sunnyberry" and "Kingsberry" in terms of cell wall metabolismrelated gene expression.

Cuticles minimize postharvest water loss, protect against pathogens, and provide mechanical support during development and postharvest storage [10]. CER1 was upregulated in "Sunnyberry" compared with that in "Kingsberry" and the opposite was true for WSD (Figure 4; Table S4). CER1 may play a crucial role in fruit wax formation [38]. Strawberries produce more alkane- than alcohol-type wax [39]. CER1 and LACS4 were relatively upregulated in "Kingsberry" after B. cinerea inoculation (Figure 5). Alkan et al. [40] reported that cuticle reinforcement occurs mainly in response to appressorium attachment. The present study indicated that cuticle reinforcement after B. cinerea perception is stronger in "Kingsberry" than in "Sunnyberry".

The effects of cuticle biosynthesis-related genes on B. cinerea resistance are unclear. Changes in cuticle composition and quantity during development differ among crops [41]. There have been few published reports on strawberry fruit cuticles and waxes. It was indirectly implied that the strawberry fruit cuticle participates in fungal pathogen resistance. Strawberries treated with ozone demonstrated relatively lower incidence of fungal decay and thicker and denser cuticles [42]. Strawberry fruits treated with pulsed light exhibited relatively reduced decay rates, enhanced firmness, and denser and more highly organized cuticles and cell wall structures [43]. $\mathrm{CO}_{2}$ treatment upregulated CER1 in strawberries and diminished fungal decay [2].

Most PR protein and R genes were upregulated in "Kingsberry" compared with those in "Sunnyberry" (Table S5). TLPs were expressed at higher levels in "Sunnyberry" than in "Kingsberry" at IG and MR. Nevertheless, the relative TLP1b mRNA decreased following $B$. cinerea inoculation (Figure 5). Thus, the involvement of $T L P 1 b$ in the defense responses of MR-stage strawberry against $B$. cinerea is unknown.

RPM1 was more strongly upregulated in "Kingsberry" than in "Sunnyberry" after B. cinerea inoculation (Figure 5). At MR, it is $\mathrm{R}$ rather than PR genes that participate in $B$. cinerea defense responses. This finding is consistent with that reported by Mehari et al. [24]. They indicated that $R$ genes were relatively upregulated in ripe strawberry fruit while PR protein expression was relatively upregulated in unripe strawberry fruit after $B$. cinerea inoculation. They also suggested that $\mathrm{R}$ gene upregulation may confer $B$. cinerea susceptibility to ripe fruit because these genes induce hypersensitive responses and cell death and facilitate necrotroph infection. Though "Kingsberry" may be more effective than "Sunnyberry" at inducing defense responses against B. cinerea, the former is paradoxically more susceptible to this fungal pathogen than the latter.

Several antioxidant systems-related genes were relatively upregulated in "Kingsberry" (Table S6). At IG and MR, two LAR genes were expressed at higher levels in "Kingsberry" than in "Sunnyberry". In strawberry fruit, LAR produces proanthocyanidins that have antifungal activity in vitro. LAR concentration is positively correlated with $B$. cinerea 
growth inhibition [44]. LAR accumulated in immature strawberry fruits after $B$. cinerea inoculation [45].

As $\mathrm{H}_{2} \mathrm{O}_{2}$ is a type of ROS, its accumulation increases antioxidant activity. $\mathrm{H}_{2} \mathrm{O}_{2}$ is also a substrate of PODs that polymerize monolignol units to lignin. At IG, the $\mathrm{H}_{2} \mathrm{O}_{2}$ content and total antioxidant activity were significantly higher in "Kingsberry" than in "Sunnyberry" after $B$. cinerea inoculation (Figure 6A,C). The relatively higher $\mathrm{H}_{2} \mathrm{O}_{2}$ content in "Kingsberry" might explain its comparative increase in total antioxidant activity. Lignin content significantly increased only in "Sunnyberry" at MR (Figure 6D). The flavonoid and lignin biosynthesis pathways share the upstream phenylpropanoid pathway. Ring et al. [46] reported that silencing the chalcone synthase gene in the flavonoid pathway increased lignin content. Hence, the flavonoid and lignin biosynthesis pathways might be mutually antagonistic. At IG, the flavonoid pathway might be a more effective defense against $B$. cinerea than lignin deposition while the opposite may be true at MR. Therefore, increases in antioxidant activity and phenolic compounds may not contribute to $B$. cinerea resistance in mature strawberries.

Figure 7 summarizes the differences between "Sunnyberry" and "Kingsberry" strawberry fruit in terms of gene expression at IG and MR and in the presence and absence of B. cinerea inoculation. Genes in red font were expressed at relatively higher levels at IG, while genes in blue font were expressed at relatively higher levels at MR.
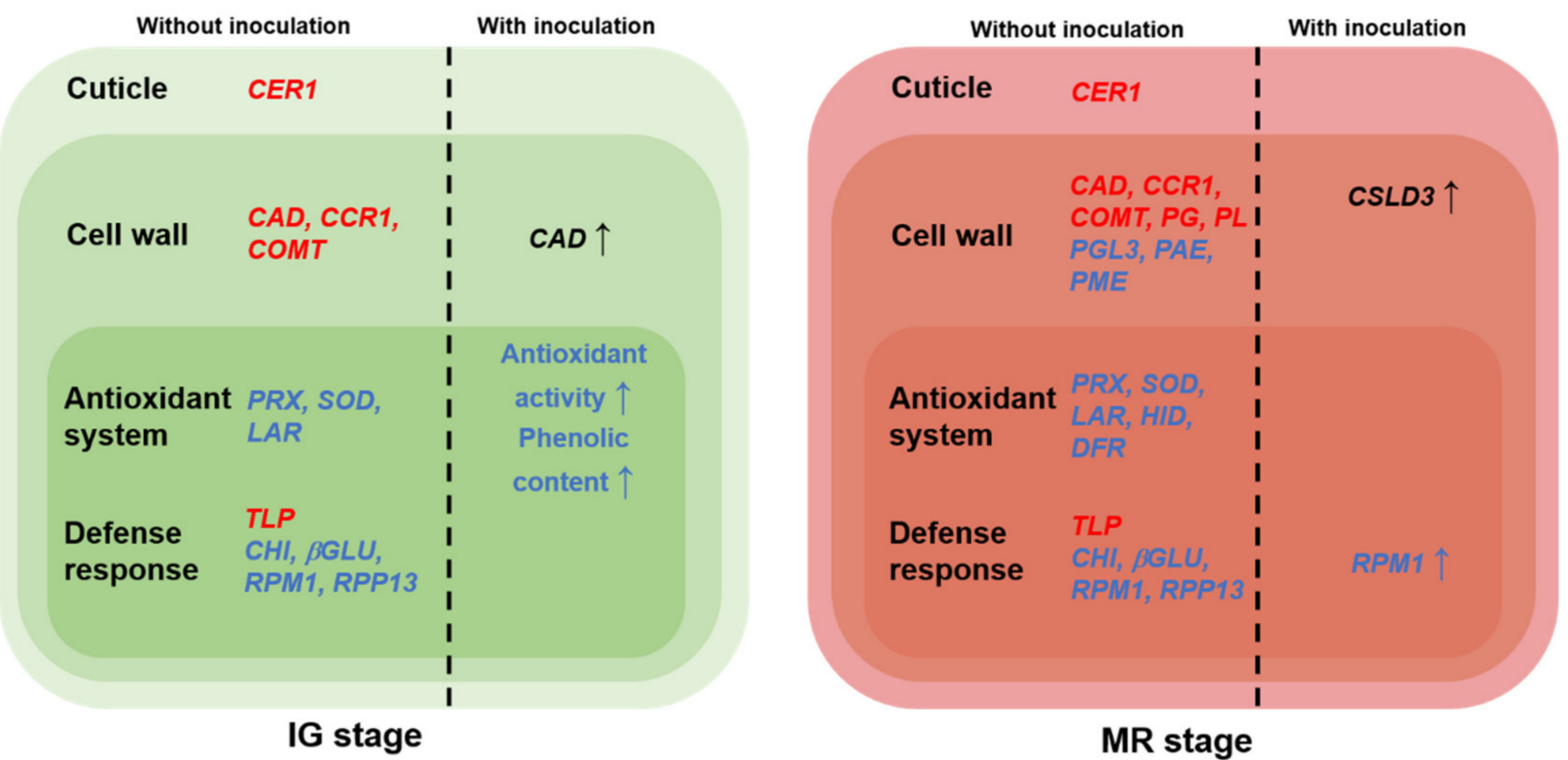

MR stage

Red characters: Higher expressions in 'Sunnyberry' cultivar (resistant)

Blue characters: Higher expressions in 'Kingsberry' cultivar (susceptible)

Figure 7. Differences between cultivars at IG and MR in terms of gene expression and defense responses against Botrytis cinerea. $\beta G L U$, glucan endo-1, 3- $\beta$-glucosidase; $C A D$, cinnamyl alcohol dehydrogenase; $C C R 1$, cinnamoyl-CoA reductase 1; CER1, protein ECERIFERUM 1; CHI, chitinase; COMT, caffeic acid O-methyltransferase; CSLD3, cellulose synthaselike protein D3; $D F R$, dihydroflavonol 4-reductase; HID, 2-hydroxyisoflavanone dehydratase; IG, immature-green; $L A R$, leucoanthocyanidin reductase; MR, mature-red; $P A E$, pectin acetylesterase; $P G$, polygalacturonase; $P G L 3$, polygalacturonase $1 \beta$-like protein 3; $P L$, pectate lyase; $P M E$, pectin methylesterase; $P R X$, peroxiredoxin; $R P M 1$, disease resistance protein $R P M$ 1-like; RPP13, disease resistance protein RPP 13-like; $S O D$, superoxide dismutase; TLP, thaumatin-like protein.

\section{Materials and Methods}

\subsection{Plant Materials}

"Sunnyberry" and "Kingsberry" strawberry plants were cultivated in a glasshouse in the Strawberry Research Institute at Nonsan, South Korea. In mid-September, strawberry 
seedlings were transplanted at a density of $9000 \mathrm{ha}^{-1}$ into soil in a plastic greenhouse. The daytime temperature was $15-25^{\circ} \mathrm{C}$ and the nighttime temperatures were $>10^{\circ} \mathrm{C}$ in the autumn and $6{ }^{\circ} \mathrm{C}$ in the winter. Fruit at the IG stage was harvested in mid-March 2020. Fruit at the MR stage was harvested in mid-April 2020. Fruit uniform in size and color was selected. IG fruit were green and $1.5-2.0 \mathrm{~cm}$ in diameter while MR fruit were red and $3.5-4.0 \mathrm{~cm}$ in diameter. The fruit were immediately transported to the laboratory after harvest.

\subsection{B. cinerea Inoculation}

B. cinerea strain AIP1 (2006-111-00001) was obtained from the Center for Fungal Genetic Resources at Seoul National University, Seoul, South Korea, and cultured on potato dextrose agar at $25^{\circ} \mathrm{C}$. A conidial suspension was prepared using a 3-week culture. The conidia were collected with $2 \mathrm{~mL}$ sterile distilled water and filtered through four layers of gauze. The concentration of the conidial suspension was evaluated using a hemocytometer (Superior, Marienfeld, Germany) with a DE/Axio Imager A1 microscope (Carl Zeiss, Oberkochen, Germany) and adjusted to $1 \times 10^{5} \mathrm{~mL}^{-1}$.

IG and MR strawberry fruits were disinfected by immersion in $2 \%(v / v)$ sodium hypochlorite for $3 \mathrm{~min}$, rinsed in sterile distilled water for $2 \mathrm{~min}$, and dried for $2 \mathrm{~h}$ on a clean bench. Each fruit was inoculated by dropping $10 \mu \mathrm{L}$ conidial suspension onto its receptacle. A total of fifteen fruits for each stage were used for the inoculation, and the inoculated fruits were then stored at $25{ }^{\circ} \mathrm{C}$ and $100 \%$ relative humidity $\mathrm{n}$ a plastic box sealed with Parafilm ${ }^{\circledR}$ (Bemis Co., Neenah, WI, USA).

\subsection{Disease Assessment}

Fifteen MR fruits for each cultivar were stored at $10{ }^{\circ} \mathrm{C}$ for $10 \mathrm{~d}$, and the disease incidence rate $(\%)$ was calculated by dividing the number of decayed fruits by the total number of fruits and multiplying the quotient by 100 . The disease incidence rate was calculated twice in 2019 and 2020.

Other MR fruits were inoculated with B. cinerea and stored at $10{ }^{\circ} \mathrm{C}$ for $10 \mathrm{~d}$, and their disease indices were rated as follows: 0 , no symptoms; 1 , symptoms on $0-10 \%$ of the fruit surface; 2 , symptoms on $10-25 \%$ of the fruit surface; 3 , symptoms on $25-50 \%$ of the fruit surface; 4 , symptoms on $>50 \%$ of the fruit surface (Figure S1). The disease incidence and indices were determined by visual examination. Fruits were considered to be decayed if they presented with symptoms of fungal pathogenesis or if their tissues were very soft.

\subsection{RNA Extraction and cDNA Synthesis}

Fruit samples $0.1 \mathrm{~g}$ in weight were flash-frozen in liquid nitrogen and pulverized. Total RNA was extracted from the powders with a Ribospin Seed/Fruit total RNA isolation kit (GeneAll, Seoul, Korea) according to the manufacturer's instructions. Total RNA was extracted from MR fruit inoculated with $B$. cinerea via a slightly modified version of the method described by Reid et al. [47]. Each $0.15 \mathrm{~g}$ fruit sample was flash-frozen in liquid nitrogen and pulverized. The powder was added to $950 \mu \mathrm{L}$ pre-warmed $\left(65^{\circ} \mathrm{C}\right)$ extraction buffer ( $2 \%(w / v)$ CTAB, $2.5 \mathrm{M} \mathrm{NaCl}, 300 \mathrm{mM}$ Tris $\mathrm{HCl}(\mathrm{pH} 8.0), 25 \mathrm{mM}$ EDTA, and $2 \%(w / v)$ PVP) and the suspension was shaken vigorously. The sample was incubated in a drying oven at $65^{\circ} \mathrm{C}$ and shaken vigorously every $5 \mathrm{~min}$. The suspension was extracted twice with equal volumes of 24:1 $(v / v)$ chloroform:isoamyl alcohol and centrifuged at $3500 \times g$ and $4{ }^{\circ} \mathrm{C}$ for $15 \mathrm{~min}$. The top layer was transferred to a new tube and centrifuged at $25,000 \times \mathrm{g}$ and $4{ }^{\circ} \mathrm{C}$ for $20 \mathrm{~min}$. The supernatant was mixed with $0.1 \mathrm{vol}$ of $3 \mathrm{M} \mathrm{NaOAc}$ and $0.6 \mathrm{vol}$ isopropanol and stored at $-20^{\circ} \mathrm{C}$ for $30 \mathrm{~min}$. The sample tube was centrifuged at $3500 \times \mathrm{g}$ and $4{ }^{\circ} \mathrm{C}$ for $30 \mathrm{~min}$ to collect the nucleic acid pellet. The pellet was dissolved in $1 \mathrm{~mL}$ Tris-EDTA and mixed with 0.3 vol of $10 \mathrm{M} \mathrm{LiCl}$.

The RNA was precipitated overnight by incubation at $4{ }^{\circ} \mathrm{C}$ and collected by centrifugation at $20,000 \times g$ and $4{ }^{\circ} \mathrm{C}$ for $30 \mathrm{~min}$. The pellet was washed with $70 \%(v / v)$ ethanol and centrifuged at $3500 \times g$ and $4{ }^{\circ} \mathrm{C}$ for $5 \mathrm{~min}$. The supernatant was discarded, and the 
pellet was centrifuged at $3500 \times g$ and $4{ }^{\circ} \mathrm{C}$ for $1 \mathrm{~min}$ to evaporate any remaining ethanol. The pellet was dissolved in $50 \mu \mathrm{L}$ sterile distilled water. All solvents except the extraction buffer were ice-cold. RNA purity was assessed by gel electrophoresis. The A260:A230 and A260:A280 ratios were measured in a microplate spectrophotometer (BioTek Epoch, Winooski, VT, USA).

The total extracted RNA was used for RNA-Seq and qPCR analyses. For qPCR, cDNA was synthesized from 500 ng total RNA with a ReverTra Ace qPCR RT kit (Toyobo Co. Ltd., Osaka, Japan) according to the manufacturer's instructions.

\subsection{RNA-Seq, Data Processing, and Functional Analysis}

Total RNA from the IG and MR stages of "Sunnyberry" and "Kingsberry" strawberry fruit was used. RNA-Seq was performed at the National Instrumentation Centre for Environmental Management of Seoul National University (Seoul, Korea) on a HiSeq 2500 platform (Illumina, San Diego, CA, USA) using 151 bp paired-end reads. Low-quality $(<$ Q20), adaptor, and barcode sequences were trimmed out with Trim Galore v. 0.4.4 using the parameter "-gzip-paired". Cleaned reads were mapped to the Fragaria $\times$ ananassa octoploid "Camarosa" annotated genome [48]. To identify the DEGs, the transcript levels were calculated as transcripts per million (TPM) using CLC Genomics Workbench v. 11 (Qiagen, Hilden, Germany) and its default parameters, namely, match score $=1$, mismatch $\operatorname{cost}=2$, insertion $\operatorname{cost}=3$, deletion $\cos t=3$, length fraction $=0.5$, and similarity fraction $=0.8$. The DEGs were filtered according to the false discovery rate criteria $p<0.01$ and $\mid$ fold-change $\mid>2$. GO functional analysis was conducted using Blast2GO v. 5.2 and the NCBI (National Center for Biotechnology Information) database [49].

\section{6. qPCR Analysis}

qPCR analysis was conducted as described by Min et al. [3]. The cDNA was diluted to $100 \mathrm{ng} \mu \mathrm{L}^{-1}$ and combined with $5 \mu \mathrm{L}$ of $2 \times$ Real-Time PCR Master Mix containing SYBR Green 1 (BioFACT, Daejeon, Korea). PCR primers (Table S7) were designed with the Primer 3 Plus server (http:/ / www.bioinformatics.nl/cgi-bin/primer3plus/primer3plus. cgi). For each reaction, relative gene expression was normalized to the expression of the reference gene elongation factor 1-alpha (maker-Fvb3-3-snap-gene-215.43) by the $2^{-\Delta \Delta \mathrm{Ct}}$ method [50].

\section{7. $\mathrm{H}_{2} \mathrm{O}_{2}$ Content}

The $\mathrm{H}_{2} \mathrm{O}_{2}$ content was determined according to the method of Junglee et al. [51], with slight modifications. Each $0.15 \mathrm{~g}$ sample was flash-frozen in liquid nitrogen, pulverized, combined with $1 \mathrm{~mL}$ cold $\left(4^{\circ} \mathrm{C}\right)$ trichloroacetic acid $(0.1 \% \mathrm{w} / \mathrm{v})$, and incubated at $4{ }^{\circ} \mathrm{C}$ for $10 \mathrm{~min}$. All samples were centrifuged at $12,000 \times \mathrm{g}$ and $4{ }^{\circ} \mathrm{C}$ for $20 \mathrm{~min}$. Each $0.5 \mathrm{~mL}$ supernatant was mixed with $0.5 \mathrm{~mL}$ of $1 \mathrm{M} \mathrm{KI}$ and $0.25 \mathrm{~mL}$ of $10 \mathrm{mM}$ potassium phosphate buffer ( $\mathrm{pH}$ 7.0). The mixtures were incubated in the dark at $22{ }^{\circ} \mathrm{C}$ for $20 \mathrm{~min}$. Absorbance was measured at $390 \mathrm{~nm}$ using a microplate spectrophotometer (BioTek Epoch, Winooski, VT, USA). A standard curve was plotted using various $\mathrm{H}_{2} \mathrm{O}_{2}$ concentrations.

\subsection{Total Phenolic Content and Total Antioxidant Activity}

Each $0.2 \mathrm{~g}$ sample was flash-frozen in liquid nitrogen, pulverized, combined with $10 \mathrm{~mL}$ of $80 \%(v / v)$ methanol, vortexed for $15 \mathrm{~s}$, sonicated for $20 \mathrm{~min}$, and centrifuged at $3000 \times \mathrm{g}$ and $22{ }^{\circ} \mathrm{C}$ for $20 \mathrm{~min}$. Each supernatant was transferred to a new $15 \mathrm{~mL}$ tube, diluted with an equal volume of $80 \%(v / v)$ methanol, and used in the subsequent assays.

Total phenolic content was determined with Folin-Ciocalteu reagent [52]. Fifty microliters diluted solution and $50 \mu \mathrm{L}$ Folin-Ciocalteu reagent were added to $450 \mu \mathrm{L}$ distilled water. The mixture was vortexed briefly and incubated at $22{ }^{\circ} \mathrm{C}$ for $5 \mathrm{~min}$. Then, $150 \mu \mathrm{L}$ of $20 \%(w / v) \mathrm{Na}_{2} \mathrm{CO}_{3}$ and $200 \mu \mathrm{L}$ distilled water were added, and the mixture was incubated in the dark at $22{ }^{\circ} \mathrm{C}$ for $30 \mathrm{~min}$. Absorbance was measured at $750 \mathrm{~nm}$ using a microplate 
spectrophotometer (BioTek Epoch, Winooski, VT, USA). A standard curve was plotted using various gallic acid dilutions.

Total antioxidant activity was determined by evaluating the $\mathrm{ABTS}^{\bullet+}$ scavenging activity [53]. The $\mathrm{ABTS}^{\bullet+}$ solution was diluted with distilled water to $\mathrm{OD}_{734}=0.7$. Then, $1.2 \mathrm{~mL}$ diluted $\mathrm{ABTS}^{\bullet+}$ solution was mixed with $10 \mu \mathrm{L}$ sample. The mixture was vortexed briefly and incubated in the dark at $22{ }^{\circ} \mathrm{C}$ for $15 \mathrm{~min}$. Absorbance was measured at $734 \mathrm{~nm}$ using a microplate spectrophotometer (BioTek Epoch, Winooski, VT, USA). A standard curve was constructed using various Trolox dilutions.

\subsection{Lignin Content}

Lignin was quantified according to the method of Ring et al. [46]. Analyses were performed on $0.2 \mathrm{~g}$ samples flash-frozen in liquid nitrogen and pulverized rather than on $0.05 \mathrm{~g}$ lyophilized fruit powder. Data were reported in $\mathrm{OD}_{280} \mathrm{~g} \mathrm{FW}^{-1}$.

\subsection{Statistical Analysis}

RNA-Seq and qPCR analyses were conducted using three biological replicates $(n=3)$. $\mathrm{H}_{2} \mathrm{O}_{2}$, total phenolic, and lignin content and total antioxidant activity were determined using four biological replicates $(n=4)$. Significant differences between treatment means were determined with a two-sample $t$-test in SPSS v. 25.0 (IBM Corp., Armonk, NY, USA).

\section{Conclusions}

In the present study, we investigated transcriptomic differences between two strawberry cultivars with varying degrees of resistance to B. cinerea. The DEGs between "Sunnyberry" and "Kingsberry" at IG and MR disclosed that "Sunnyberry" exhibited relatively higher expression levels of genes related to lignin and cuticle biosynthesis. In contrast, "Kingsberry" displayed higher expression levels of genes regulating PR, R, and antioxidant system-related proteins. Examination of induced defense responses revealed that the physiological traits and the expression levels of genes controlling cell wall metabolism, cuticle biosynthesis, and defense response varied with cultivar and developmental stage. Our study demonstrated that "Sunnyberry" and "Kingsberry" differed in terms of their pre-formed physical barriers and induced defense responses. However, their defense strategies were effective at MR and contributed to B. cinerea resistance.

Supplementary Materials: The following are available online at https:/ / www.mdpi.com/1422-006 $7 / 22 / 4 / 1518 /$ s1.

Author Contributions: Conceptualization, E.J.L. and K.L. Methodology, E.J.L. and K.L. Investigation, K.L., J.G.L., K.M., J.H.C., S.L., and E.J.L. Formal analysis and original draft preparation, K.L. and E.J.L. Wring-review, K.L., J.G.L., and E.J.L. Funding acquisition, E.J.L. All authors have read and agreed to the published version of the manuscript.

Funding: This work was supported by the Basic Science Research Program through the National Research Foundation of Korea (NRF; Grant No. 2016R1A1A1A05919210 to E.J.L.) funded by the Ministry of Education, Science, and Technology (MEST). It was also funded by the Rural Development Administration of the Republic of Korea (RDA; Grant No. PJ01364804 to E.J.L.). Other funding was provided by the Korea Institute of Planning and Evaluation for Technology in Food, Agriculture and Forestry (IPET; Grant No. 617068-05-1-WT111 to E.J.L.) via the Export Promotion Technology Development Program funded by the Ministry of Agricultural, Food and Rural Affairs (MAFRA) of the Republic of Korea.

Institutional Review Board Statement: Not applicable.

Informed Consent Statement: Not applicable.

Data Availability Statement: All data are available upon reasonable request.

Conflicts of Interest: The authors declare no conflict of interest. 


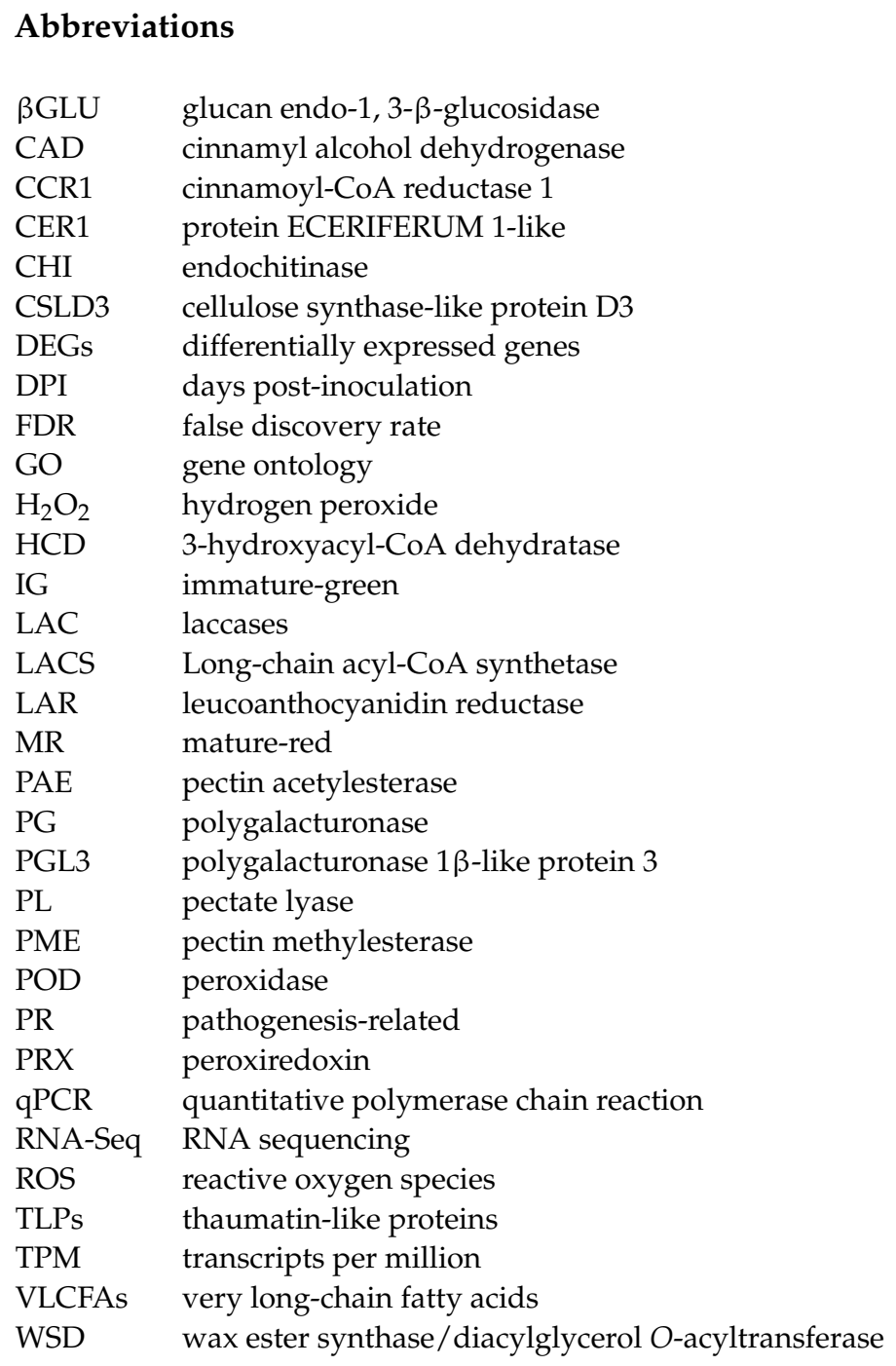

\section{References}

1. KATI. Available online: https://www.kati.net/product/basisInfo.do?lcdCode=MD149 (accessed on 28 October 2020).

2. Bang, J.; Lim, S.; Yi, G.; Lee, J.G.; Lee, E.J. Integrated transcriptomic-metabolomic analysis reveals cellular responses of harvested strawberry fruit subjected to short-term exposure to high levels of carbon dioxide. Postharvest Biol. Technol. 2019, 148, 120-131. [CrossRef]

3. Min, K.; Yi, G.; Lee, J.G.; Kim, H.S.; Hong, Y.; Choi, J.H.; Lim, S.; Lee, E.J. Comparative transcriptome and metabolome analyses of two strawberry cultivars with different storability. PLOS ONE 2020, 15, e0242556. [CrossRef] [PubMed]

4. Barnes, M.F.; Patchett, B.J. Cell wall degrading enzymes and the softening of senescent strawberry fruit. J. Food Sci. 1979, 41, 1392-1396. [CrossRef]

5. Petrasch, S.; Knapp, S.J.; Van Kan, J.A.; Blanco-Ulate, B. Grey mould of strawberry, a devastating disease caused by the ubiquitous necrotrophic fungal pathogen Botrytis cinerea. Mol. Plant Pathol. 2019, 20, 877-892. [CrossRef]

6. Pawlowski, M.L.; Hartman, G.L. Infection mechanisms and colonization patterns of fungi associated with soybean. In Fungal Pathogenicity; Sultan, S., Ed.; IntechOpen: Rijeka, Croatia, 2016; pp. 25-42.

7. Williamson, B.; Tudzynski, B.; Tudzynski, P.; Van Kan, J.A. Botrytis cinerea: The cause of grey mould disease. Mol. Plant Pathol. 2007, 8, 561-580. [CrossRef]

8. Alkan, N.; Fortes, A.M. Insights into molecular and metabolic events associated with fruit response to post-harvest fungal pathogens. Front. Plant Sci. 2015, 6, 889. [CrossRef]

9. Hückelhoven, R. Cell wall-associated mechanisms of disease resistance and susceptibility. Annu. Rev. Phytopathol. 2007, 45, 101-127. [CrossRef]

10. Lara, I.; Belge, B.; Goulao, L.F. The fruit cuticle as a modulator of postharvest quality. Postharvest Biol. Technol. 2014, 87, 103-112. [CrossRef]

11. Ziv, C.; Zhao, Z.; Gao, Y.G.; Xia, Y. Multifunctional roles of plant cuticle during plant-pathogen interactions. Front. Plant Sci. 2018, 9, 1088. [CrossRef] 
12. AbuQamar, S.; Moustafa, K.; Tran, L.S. Mechanisms and strategies of plant defense against Botrytis cinerea. Crit. Rev. Biotechnol. 2017, 37, 262-274. [CrossRef]

13. Pandey, D.; Rajendran, S.R.C.K.; Gaur, M.; Sajeesh, P.K.; Kumar, A. Plant defense signaling and responses against necrotrophic fungal pathogens. J. Plant Growth Regul. 2016, 35, 1159-1174. [CrossRef]

14. Xiong, J.S.; Zhu, H.Y.; Bai, Y.B.; Liu, H.; Cheng, Z.M. RNA sequencing-based transcriptome analysis of mature strawberry fruit infected by necrotrophic fungal pathogen Botrytis cinerea. Physiol. Mol. Plant Pathol. 2018, 104, 77-85. [CrossRef]

15. Robert-Seilaniantz, A.; Grant, M.; Jones, J.D. Hormone crosstalk in plant disease and defense: More than just jasmonate-salicylate antagonism. Annu. Rev. Phytopathol. 2011, 49, 317-343. [CrossRef] [PubMed]

16. Sharma, P.; Jha, A.B.; Dubey, R.S.; Pessarakli, M. Reactive oxygen species, oxidative damage, and antioxidative defense mechanism in plants under stressful conditions. J. Bot. 2012, 2012, 217037. [CrossRef]

17. Bai, T.T.; Xie, W.B.; Zhou, P.P.; Wu, Z.L.; Xiao, W.C.; Zhou, L.; Sun, J.; Ruan, X.L.; Li, H.P. Transcriptome and expression profile analysis of highly resistant and susceptible banana roots challenged with Fusarium oxysporum f. sp. cubense tropical race 4 . PLoS ONE 2013, 8, e73945.

18. Miyaji, N.; Shimizu, M.; Miyazaki, J.; Osabe, K.; Sato, M.; Ebe, Y.; Takada, S.; Kaji, M.; Dennis, E.S.; Fujimoto, R.; et al. Comparison of transcriptome profiles by Fusarium oxysporum inoculation between Fusarium yellows resistant and susceptible lines in Brassica rapa L. Plant Cell Rep. 2017, 36, 1841-1854. [CrossRef]

19. Pan, Y.; Liu, Z.; Rocheleau, H.; Fauteux, F.; Wang, Y.; McCartney, C.; Ouellet, T. Transcriptome dynamics associated with resistance and susceptibility against fusarium head blight in four wheat genotypes. BMC Genom. 2018, 19, 642. [CrossRef]

20. Cui, J.; Luan, Y.; Jiang, N.; Bao, H.; Meng, J. Comparative transcriptome analysis between resistant and susceptible tomato allows the identification of lnc RNA 16397 conferring resistance to Phytophthora infestans by co-expressing glutaredoxin. Plant J. 2017, 89, 577-589. [CrossRef]

21. Wang, L.; Wang, Y.; Cao, H.; Hao, X.; Zeng, J.; Yang, Y.; Wang, X. Transcriptome analysis of an anthracnose-resistant tea plant cultivar reveals genes associated with resistance to Colletotrichum camelliae. PLoS ONE 2016, 11, e0148535. [CrossRef]

22. Blanco-Ulate, B.; Vincenti, E.; Powell, A.L.; Cantu, D. Tomato transcriptome and mutant analyses suggest a role for plant stress hormones in the interaction between fruit and Botrytis cinerea. Front. Plant Sci. 2013, 4, 142. [CrossRef]

23. Haile, Z.M.; Malacarne, G.; Pilati, S.; Sonego, P.; Moretto, M.; Masuero, D.; Vrhovsek, U.; Engelen, K.; Baraldi, E.; Moser, C. Dual transcriptome and metabolic analysis of Vitis vinifera cv. Pinot Noir berry and Botrytis cinerea during quiescence and egressed infection. Front. Plant Sci. 2020, 10, 1704. [CrossRef] [PubMed]

24. Mehari, Z.H.; Guzman, N.D.; Grace, E.; Moretto, M.; Sonego, P.; Engelen, K.; Zoli, L.; Moser, C.; Baraldi, E. Transcriptome profiles of strawberry (Fragaria vesca) fruit interacting with Botrytis cinerea at different ripening stages. Front. Plant Sci. 2019, $10,1131$.

25. Dong, W.; Lu, Y.; Yang, T.; Trouth, F.; Lewers, K.S.; Daughtry, C.S.; Cheng, Z.M. Effect of genotype and plastic film type on strawberry fruit quality and post-harvest shelf life. Int. J. Fruit Sci. 2020, 20, 750-767. [CrossRef]

26. Park, J.; Cui, Y.; Kang, B.H. AtPGL3 is an Arabidopsis BURP domain protein that is localized to the cell wall and promotes cell enlargement. Front. Plant Sci. 2015, 6, 412. [CrossRef]

27. Kim, S.J.; Kim, K.W.; Cho, M.H.; Franceschi, V.R.; Davin, L.B.; Lewis, N.G. Expression of cinnamyl alcohol dehydrogenases and their putative homologues during Arabidopsis thaliana growth and development: Lessons for database annotations? Phytochemistry 2007, 68, 1957-1974. [CrossRef]

28. Trivedi, P.; Nguyen, N.; Hykkerud, A.L.; Häggman, H.; Martinussen, I.; Jaakola, L.; Karppinen, K. Developmental and environmental regulation of cuticular wax biosynthesis in fleshy fruits. Front. Plant Sci. 2019, 10, 431. [CrossRef]

29. Bowman, S.M.; Free, S.J. The structure and synthesis of the fungal cell wall. Bioessays 2006, 28, 799-808. [CrossRef]

30. Singh, N.K.; Kumar, K.R.R.; Kumar, D.; Shukla, P.; Kirti, P.B. Characterization of a pathogen induced thaumatin-like protein gene AdTLP from Arachis diogoi, a wild peanut. PLoS ONE 2013, 8, e83963. [CrossRef]

31. Sekhwal, M.K.; Li, P.; Lam, I.; Wang, X.; Cloutier, S.; You, F.M. Disease resistance gene analogs (RGAs) in plants. Int. J. Mol. Sci. 2015, 16, 19248-19290. [CrossRef]

32. Liebthal, M.; Maynard, D.; Dietz, K.J. Peroxiredoxins and redox signaling in plants. Antioxid. Redox Signal. 2018, 28 , 609-624. [CrossRef]

33. Cantu, D.; Vicente, A.R.; Labavitch, J.M.; Bennett, A.B.; Powell, A.L. Strangers in the matrix: Plant cell walls and pathogen susceptibility. Trends Plant Sci. 2008, 13, 610-617. [CrossRef] [PubMed]

34. Suutarinen, J.; Änäkäinen, L.; Autio, K. Comparison of light microscopy and spatially resolved Fourier transform infrared (FT-IR) microscopy in the examination of cell wall components of strawberries. LWT Food Sci. Technol. 1998, 31, 595-601. [CrossRef]

35. Li, Z.; Wang, N.; Wei, Y.; Zou, X.; Jiang, S.; Xu, F.; Wang, H.; Shao, X. Terpinen-4-ol enhances disease resistance of postharvest strawberry fruit more effectively than tea tree oil by activating the phenylpropanoid metabolism pathway. J. Agric. Food Chem. 2020, 68, 6739-6747. [CrossRef] [PubMed]

36. Salentijn, E.M.; Aharoni, A.; Schaart, J.G.; Boone, M.J.; Krens, F.A. Differential gene expression analysis of strawberry cultivars that differ in fruit-firmness. Physiol. Plant. 2003, 118, 571-578. [CrossRef]

37. Caño-Delgado, A.; Penfield, S.; Smith, C.; Catley, M.; Bevan, M. Reduced cellulose synthesis invokes lignification and defense responses in Arabidopsis thaliana. Plant J. 2003, 34, 351-362. [CrossRef] 
38. Wang, J.; Hao, H.; Liu, R.; Ma, Q.; Xu, J.; Chen, F.; Cheng, Y.; Deng, X. Comparative analysis of surface wax in mature fruits between Satsuma mandarin (Citrus unshiu) and 'Newhall'navel orange (Citrus sinensis) from the perspective of crystal morphology, chemical composition and key gene expression. Food Chem. 2014, 153, 177-185. [CrossRef]

39. Vallarino, J.G.; Merchante, C.; Sánchez-Sevilla, J.F.; de Luis Balaguer, M.A.; Pott, D.M.; Ariza, M.T.; Casañal, A.; Posé, D.; Vioque, A.; Amaya, I.; et al. Characterizing the involvement of FaMADS9 in the regulation of strawberry fruit receptacle development. Plant Biotechnol. J. 2020, 18, 929-943. [CrossRef]

40. Alkan, N.; Friedlander, G.; Ment, D.; Prusky, D.; Fluhr, R. Simultaneous transcriptome analysis of Colletotrichum gloeosporioides and tomato fruit pathosystem reveals novel fungal pathogenicity and fruit defense strategies. New Phytol. 2015, 205, 801-815. [CrossRef]

41. Lara, I.; Belge, B.; Goulao, L.F. A focus on the biosynthesis and composition of cuticle in fruits. J. Agric. Food Chem. 2015, 63, 4005-4019. [CrossRef]

42. Contigiani, E.V.; Jaramillo-Sánchez, G.; Castro, M.A.; Gómez, P.L.; Alzamora, S.M. Postharvest quality of strawberry fruit (Fragaria $\times$ ananassa Duch cv. Albion) as affected by ozone washing: Fungal spoilage, mechanical properties, and structure. Food Bioprocess Technol. 2018, 11, 1639-1650. [CrossRef]

43. Duarte-Molina, F.; Gómez, P.L.; Castro, M.A.; Alzamora, S.M. Storage quality of strawberry fruit treated by pulsed light: Fungal decay, water loss and mechanical properties. Innov. Food Sci. Emerg. Technol. 2016, 34, 267-274. [CrossRef]

44. Hébert, C.; Charles, M.T.; Gauthier, L.; Willemot, C.; Khanizadeh, S.; Cousineau, J. Strawberry proanthocyanidins: Biochemical markers for Botrytis cinerea resistance and shelf-life predictability. IV Int. Strawb. Symp. 2000, 567, 659-662. [CrossRef]

45. Jersch, S.; Scherer, C.; Huth, G.; Schlösser, E. Proanthocyanidins as basis for quiescence of Botrytis cinerea in immature strawberry fruits. J. Plant Dis. Prot. 1989, 96, 365-378.

46. Ring, L.; Yeh, S.Y.; Hücherig, S.; Hoffmann, T.; Blanco-Portales, R.; Fouche, M.; Villatoro, C.; Denoyes, B.; Monfort, A.; Caballero, J.L.; et al. Metabolic interaction between anthocyanin and lignin biosynthesis is associated with peroxidase FaPRX27 in strawberry fruit. Plant Physiol. 2013, 163, 43-60. [CrossRef] [PubMed]

47. Reid, K.E.; Olsson, N.; Schlosser, J.; Peng, F.; Lund, S.T. An optimized grapevine RNA isolation procedure and statistical determination of reference genes for real-time RT-PCR during berry development. BMC Plant Biol. 2006, 6, 27. [CrossRef]

48. Edger, P.P.; Poorten, T.J.; VanBuren, R.; Hardigan, M.A.; Colle, M.; McKain, M.R.; Smith, R.D.; Teresi, S.J.; Nelson, A.D.L.; Wai, C.M.; et al. Origin and evolution of the octoploid strawberry genome. Nat. Genet. 2019, 51, 541-547. [CrossRef] [PubMed]

49. Cornesa, A.; Götz, S.; García-Gómez, J.M.; Terol, J.; Talón, M.; Robles, M. Blast2GO: A universal tool for annotation, visualization and analysis in functional genomics research. Bioinformatics 2005, 21, 3674-3676. [CrossRef]

50. Livak, K.J.; Schmittgen, T.D. Analysis of relative gene expression data using real-time quantitative PCR and the $2^{-\Delta \Delta C T}$ method. Methods 2001, 25, 402-408. [CrossRef]

51. Junglee, S.; Urban, L.; Sallanon, H.; Lopez-Lauri, F. Optimized assay for hydrogen peroxide determination in plant tissue using potassium iodide. Am. J. Anal. Chem. 2014, 5, 730. [CrossRef]

52. Singleton, V.L.; Rossi, J.A. Colorimetry of total phenolics with phosphomolybdic-phosphotungstic acid reagents. Am. J. Enol. Vitic. 1965, 16, 144-158.

53. Re, R.; Pellegrini, N.; Proteggente, A.; Pannala, A.; Yang, M.; Rice-Evans, C. Antioxidant activity applying an improved ABTS radical cation decolorization assay. Free Radic. Biol. Med. 1999, 26, 1231-1237. [CrossRef] 